\title{
A Review of Pathways to Carbon Neutrality from Renewable Energy and Carbon Capture
}

\author{
Qianji Zhao ${ }^{1, *}$ \\ ${ }^{1}$ School of University of New South Wales, Sydney, New South Wales, 2032 (post), Australia.
}

\begin{abstract}
The greenhouse gas represented by carbon dioxide is having a negative impact on the earth's ecology. The goal of carbon neutrality is to reduce carbon emissions to zero through complete elimination or dynamic balance. Therefore, achieving the goal of carbon neutrality is conducive to restoring the earth's ecology and reducing global temperature. The main ways to achieve carbon neutrality include the use of renewable energy to replace fossil energy and carbon capture and sequestration. There is no carbon dioxide involved in the process of renewable energy production, and carbon capture and storage can directly eliminate carbon dioxide. This article reviews the ways to achieve carbon neutrality: the status quo, advantages and disadvantages of renewable energy and carbon capture and sequestration, and analyzes the current development and problems and challenges of carbon neutrality through examples.
\end{abstract}

\section{Introduction}

Carbon neutrality refers to the process of balancing carbon dioxide emissions and eliminating or completely eliminating carbon dioxide emissions in the related carbon dioxide release processes [1] such as transportation, energy production, agriculture, and industrial processes to achieve net zero carbon dioxide emissions [2]. The process of carbon neutrality started with the Paris Agreement in 2015 [3]. At this meeting, countries put forward an agreement to achieve global carbon neutrality between 2050 and 2100, and requested that emissions reduction progress be updated every five years [4]. At present, the average temperature in the world is rising. The realization of carbon neutrality can effectively avoid carbon dioxide emissions, reduce the greenhouse effect, and thus lower the temperature, which is of great significance for maintaining the world's ecological balance [5].

The main way to achieve carbon neutrality is to reduce or empty the carbon footprint [6] as much as possible. In order to achieve this goal, direct or indirect elimination of carbon emissions is the current method. The direct method is generally carbon capture and sequestration, while the indirect method is to use renewable energy to replace fossil energy. Carbon capture and sequestration (CCS) is to remove and collect carbon compounds through combustion under different conditions, and to store the collected carbon through injection into the ground or biodegradation [7]. In 2019, the total annual carbon emissions were about 59100 MT, and the carbon dioxide produced by fossil fuels was about 34169 MT [8]. Therefore, the development of renewable energy to replace fossil fuels can significantly reduce carbon emissions and achieve carbon neutrality.
This article summarizes the development of carbon neutrality, lists its development direction, and lists the status quo of some examples of carbon neutrality, discusses the advantages and disadvantages, and puts forward the challenges it faces. In short, the focus of this review is:

1) Development status, challenges and development directions of major renewable energy;

2) Effective ways of carbon capture and sequestration;

3) Some existing research on carbon neutrality and the problems faced by carbon neutral development.

\section{Renewable energy}

Renewable energy refers to the energy source obtained from the natural process of continuous supplementation. Renewable energy plays an important role in the realization of the concept of carbon neutrality. Compared with the most widely used fossil energy, renewable energy uses carbon neutral resources. The world's primary energy consumption was $583.9 \mathrm{EJ}$, the renewable energy consumption was $66.62 \mathrm{EJ}$ [8], which accounts for $11.4 \%$. As the cost of renewable energy devices drops, the development of renewable energy has shown a positive trend. The carbon emission reduction effect brought by renewable energy is one way to achieve carbon neutrality. The development goal of renewable energy is fully renewable energy: the use of renewable energy in primary energy. 


\subsection{Wind power}

Wind energy refers to the use of wind as a resource to drive wind turbines to turn generators to generate electricity. Its power generation form is divided into onshore wind power and offshore wind power. In 2019, the world's wind power generation capacity was $1270.2 \mathrm{TWh}$ [8]. Wind is the raw material for wind power generation, so the use of wind is the key to wind power generation. In wind utilization, it is not only necessary to realize the collection of wind, but also to protect the equipment when the wind is too strong.

The wind turbine collects wind energy and converts it into wind power (Fig. 1). General wind turbines are designed with large horizontal axis wind turbines (HAWTs). And future development will be based on this.

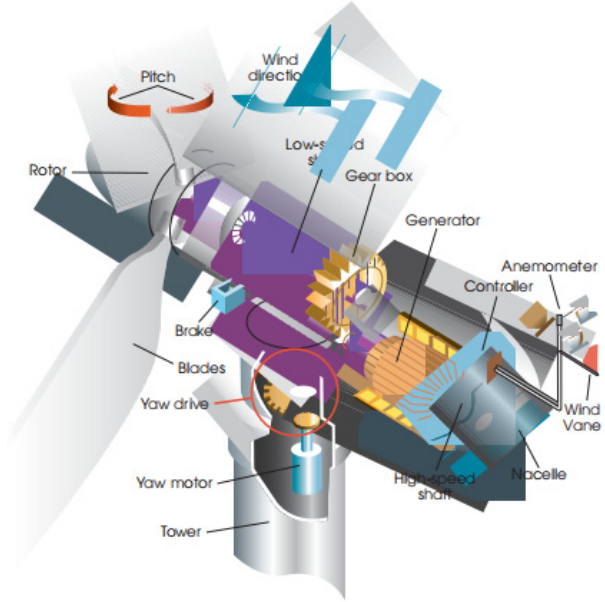

Fig. 1. Typical modern high-power wind turbine structure [9]

HAWTs generally have $2 \mathrm{MW}, 3 \mathrm{MW}, 5 \mathrm{MW}, 7 \mathrm{MW}$ and 10MW models (Fig. 2):

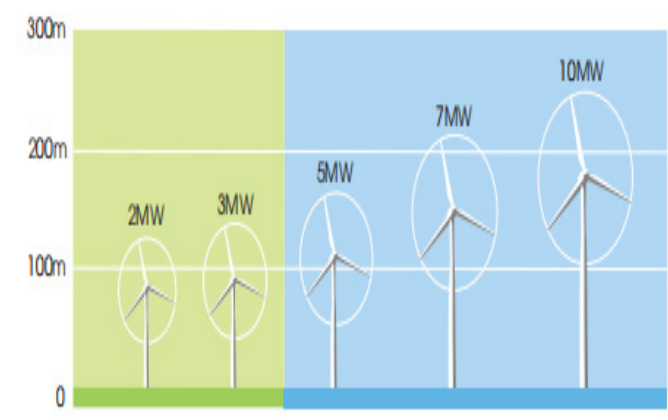

Fig. 2. Size models of HAWTs

The Betz limit proposed by Albert Bates points out that in an ideal state, the limit efficiency at which the rotor converts wind energy into mechanical energy is $16 / 27$. The conditions for reaching the Betz limit are:

1) The air is incompressible and flows evenly.

2) Energy will not be lost due to friction.

3) The change of air pressure is uniform on the rotor disk [10].

In order to achieve a higher efficiency of the rotor, the blade design of the wind turbine is curved. The current twist angles are generally $72^{\circ}, 81^{\circ}$ and $84^{\circ}$ [11].

The establishment of large-scale wind power is conducive to achieving carbon neutrality, but its limitations cannot be ignored. The transmission end of the traditional power grid is generally thermal power and hydropower, which can be connected to the grid according to the reactive power demand and total demand of the grid. Wind energy is an uncontrollable and non-storable energy source. When there is no wind, wind power generation cannot be carried out. When the wind speed is high, the electricity generated is too large. This has no effect when wind energy is used as one of the energy sources of the grid system, but it will appear when wind energy is used as the main energy source in the future [9].

At present, wind farms are often distributed in less populated areas. With the development of urbanization, the location of wind farms may be close to cities that appear in the future. In addition to the lesser impact on the landscape, the noise generated by the rotation of the fan and the reflection of the fan blades in sunny weather may have a certain negative impact on the residents $[12,13]$.

According to a survey conducted by the Royal Society for the Protection of Birds [13], a large number of birds and bats died due to the impact of wind turbines, air pressure, or noise. In 2005, the discovery of hundreds of bat carcasses in a wind farm in Long Bone Mountain in the United States also confirmed this situation [14]. The tidal flats in offshore areas may also be affected by the establishment of wind farms. On the other hand, offshore wind power has certain benefits to the living environment of fish. The foundation of wind farms will be used as artificial coral reefs for fish to survive [15]. Therefore, based on the large-scale application of wind power to replace fossil energy and maintain the local environment, it is very important to propose a plan that satisfies all parties.

\subsection{Solar power}

Solar energy is an inexhaustible energy source. Photovoltaic power generation is the process of converting solar energy into electrical energy. Photovoltaic power generation can directly use photovoltaic cells or indirectly use concentrated solar technology to generate electricity. The efficiency of traditional single-junction PV cells can now reach about $33.16 \%$ [16]. Concentrated solar energy has broad development prospects due to its high capacity, high energy storage and high efficiency. Therefore, the photovoltaic industry plays an important role in replacing traditional fossil energy sources and achieving carbon neutrality.

\subsubsection{Photovoltaic cells}

Photovoltaic cells (PV cells) refer to devices that generate electricity through the photovoltaic effect (Fig. 3). The research of photovoltaic cells is concentrated in the field of materials, and it is the current research direction to find materials with high efficiency and high economy. The ideal photovoltaic cell material should have these characteristics $[17,18]$ :

1) It has a band structure;

2) It has a bandgap of $1.1-1.7 \mathrm{eV}$;

3) Easy to obtain and can be reproduced in large quantities; 
4) Non-toxic or low toxicity;

5) High photovoltaic conversion efficiency and excellent stability.

\section{Sunlight}

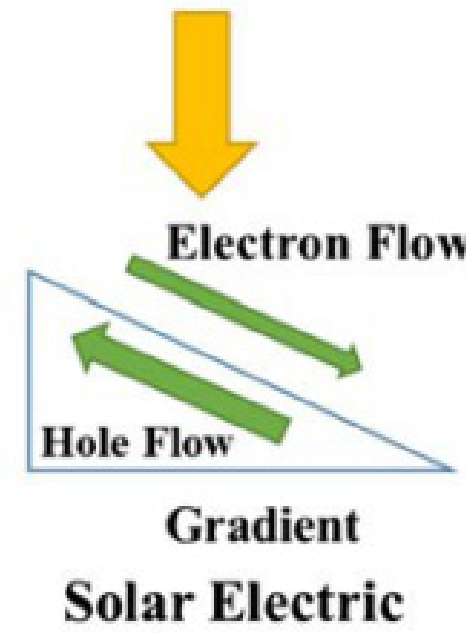

Fig. 3. Photovoltaic cell power generation process [19]

\section{(1) First-generation PV cells}

The First-generation PV cells are called crystalline silicon solar cell. Crystalline silicon solar cells are currently the most common and the earliest and most mature solar cells on the market. The monocrystalline silicon cell is composed of a silicon PN junction, and its conversion rate is up to $25 \%$. The polycrystalline silicon cell is made by melting the monocrystalline silicon to fix the crystal direction and slice, and its conversion rate is $20.4 \%$ [20].

The PV conversion rate of monocrystalline silicon solar cells is significantly higher. However, polycrystalline silicon solar cells are cheaper and can significantly reduce defects in silicon crystals through processes. With the development of ribbon silicon technology, the cost of silicon crystal solar cells will further decrease. Emitter wrap-through (EWT) refers to the process of drilling holes in solar cells to achieve a higher surface area and improve efficiency [21].

The advantages of the first generation of batteries are higher efficiency at lower temperatures and higher power per unit area. However, its main disadvantage is its low performance under high temperature conditions.

\section{(2) Second-generation PV cells}

Second-generation solar cells are called thin-film solar cells. The current industrialization includes amorphous silicon (AS) solar cells, cadmium telluride (CdTe) solar cells and copper indium gallium selenide (CIGS) solar cells.

AS cells are produced with a plasma-enhanced chemical reactor to decompose silane gas and deposit it on a carrier. Their material and production costs are cheap and cost-effective, but their PV efficiency is only about $10.1 \%$, and the voltage output is unstable after a long time of use, which tends to be reduced by about $20 \%$ [22]. The PV efficiency of CdTe cells is about $17 \%$, and the production process is chemically depositing CdTe through evaporation on a substrate. However, the toxicity of the materials and the low yield of Te limit their yield. The CIGS cell has a higher efficiency than the former two. It has a PV efficiency of $20 \%$ under laboratory conditions, and an efficiency of $12-14 \%$ under commercial conditions However, the toxicity of their materials still limits their development [23].

\section{(3) Third-generation PV cells}

The third-generation PV cells mainly include concentrating and organic solar cells, etc., which are environmentally friendly and high in efficiency. They are characterized by the addition of organic matter and nanotechnology to the process. Organic solar (OS) cells and dye-sensitized (DS) solar cells are the major thirdgeneration cells.

In an OS cell, an organic light-absorbing layer is placed between two different electrodes. One of the electrodes is transparent or semi-transparent, usually composed of indium tin oxide (ITO). The other electrode is usually composed of aluminum, and other materials such as magnesium and gold are sometimes used. The organic light-absorbing layer is composed of a photosensitive conjugated polymer (such as phthalocyanine) or a mixture of small molecules and fullerene compounds to absorb light and generate a voltage in the process [24-26].

In DS cells, light is absorbed by a sensitizer (ruthenium-polypyridine dye) fixed on the surface of a broadband semiconductor. At the interface, charge separation is promoted through the injection of photoinduced electrons from the dye into the conduction band of the solid ( $\mathrm{TiO} 2)$. Electrons are then diffuse in the conduction band as a result of electron concentration gradient to the charge collector or anode [27].

However, the technology of the third-generation PV cell is not yet mature, so the market share is relatively small, about $1 \%$. But their pollution-free and high efficiency indicate a better future development prospect.

\subsubsection{Concentrated solar power}

At present, CSP technology has these characteristics: Parabolic troughs, Dish-engine systems, Power towers, and Linear Fresnel reflectors.

Parabolic trough's condenser is composed of a parabolic reflector that concentrates the reflected light on a receiver at the focal line. The receiver is a tube directly above the middle of the parabolic mirror, and the tube is filled with working fluid. The mirror tracks the sun during the day by following a single axis. When flowing through the receiver, the working fluid (such as molten salt) is heated to $150-350{ }^{\circ} \mathrm{C}$ and then used as a heat source for the power generation system [28, 29]. The earliest commercial parabolic trough power plant in the world is Solar Energy Generating Systems (SEGS) in California, USA [30].

The Dish-engine system is a combination system. The working principle of the dish system is to gather the incident sunlight at the focal point through a large parabolic curved condensing mirror, and set a receiver to capture heat and convert it into electrical energy. Generally, the dish and Stirling engine are coupled in a Stirling dish 
system. It has the highest efficiency of currently known solar technology, about 30\% [31].

The power tower system uses a large number of directional reflectors to concentrate sunlight on a central heat exchanger mounted on the top of the tower. The receiver can generally collect $100 \mathrm{MW}$ of radiant power and generate a high temperature of $1100^{\circ} \mathrm{C}$. These power towers are equipped with energy storage systems to provide continuous power throughout the day. Traditional towers use water/steam as the working fluid, while modern towers are experimenting with molten salt [30-32].

Linear Fresnel reflector system consists of many thin flat mirror strips that concentrate sunlight onto a tube, which passes through the pumped working fluid. Planar mirrors allow more reflective surfaces than a parabolic reflector in the same space, thereby capturing more available sunlight, and they are much cheaper than parabolic reflectors [33].

\subsubsection{Problems of solar energy}

Because of its rich resources and environmentally friendly nature, solar energy will be used as one of the main energy sources to replace traditional fossil energy in the future. In order to achieve this goal, there are still many problems that need to be resolved.

The first is the technical problem. Compared with other methods of power generation, PV cell technology needs to improve its economic benefits. Because of its low efficiency and weather constraints, PV cells have low yields compared to other energy sources. As for CSP technology, because of its working method, it can avoid the influence caused by the weather to a certain extent, so it is its development prospect to improve the heat capacity of its working fluid.

The second is economic issues. Solar energy has been developing for a long time. In 2017, the price of photovoltaic equipment was $\$ 3500 / \mathrm{KW}$ (Fig. 5), but it was still too expensive compared to other energy sources. The figure below shows the price comparison of some energy sources. It can be concluded that solar energy is more expensive than other energy sources or even renewable energy [34, 35].

In addition, for PV cells, because they are greatly affected by the weather, the development of supporting energy storage systems is also an important way to solve their instability.

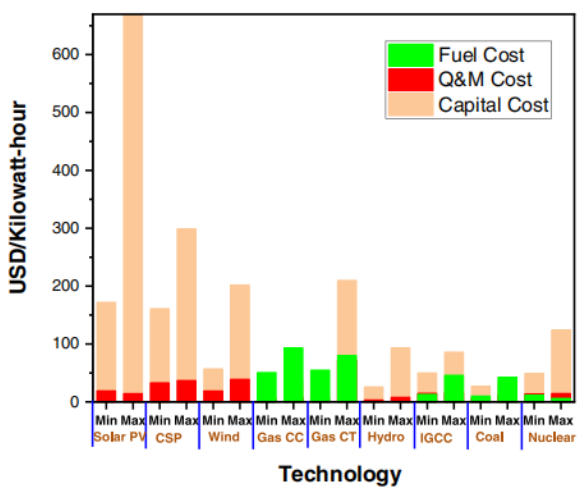

Fig. 4. Average power generation cost of different power generation methods [35]

\subsection{Hydropower}

In 2019 , the world's hydropower generation capacity was $4306 \mathrm{TWh}[8]$.

\subsubsection{Types of hydropower}

Hydropower is generally divided into conventional hydropower, pumped-storage hydroelectricity, run-of-theriver hydroelectricity, and tide power.

1) Conventional hydropower station uses theconventional dammed method. This is currently the most widely used form of hydropower. The working principle of a conventional hydropower station is to convert the potential energy of water into electrical energy through the turbine in the dam [36] (Fig. 5). The largest conventional hydropower station in the world is China's Three Gorges Dam, with a total installed capacity of 22500MW [37].

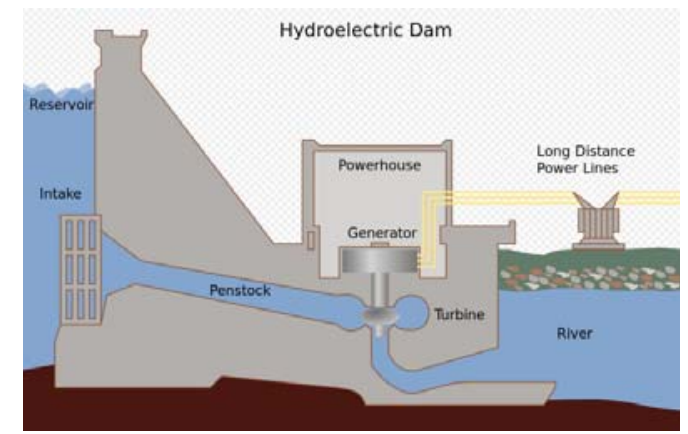

Fig. 5. Structure of conventional hydropower station [38]

2) Pumped-storage hydroelectricity is also called pumped hydroelectric energy storage. This is a form of power generation used to balance the load. During the low electricity demand, the excess electric energy is transferred from the low to the high, thereby becoming the potential energy of water. The potential energy of water is converted into electricity during the peak period of electricity demand (Fig. 6). In this way, energy is dispatched reasonably, and income is generated through price difference. This technology can also be used at the same time as conventional hydropower stations, which can save resources better [39].

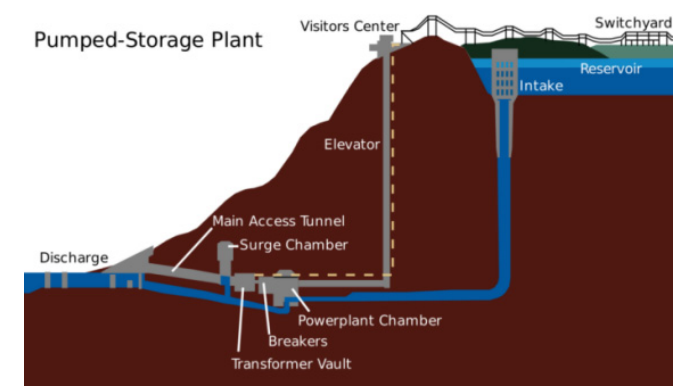

Fig. 6. Structure of Raccoon Mountain Pumped-Storage Plant in Tennessee, USA [41]

3) The run-of-the-river hydroelectricity is small in scale and generally has no water storage device or only limited water storage capacity. Its working principle is 
similar to that of a conventional hydropower station, which generates electricity by transporting upstream water to turbines through penstock pipes (Fig. 7). Compared with a conventional hydropower station, a run-of-the-river hydroelectricity station has less impact on the downstream due to limited water storage, and is a safer but smaller form of power generation [41, 42].

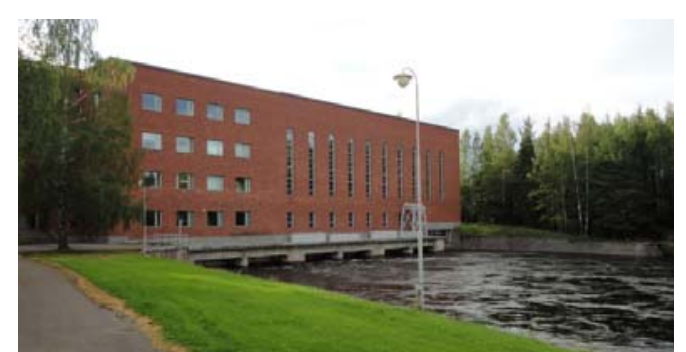

Fig. 7. Mankala Power Station along the Kymi River in Iitti, Finland [43]

4) Tidal energy comes from the gravitational interaction with the moon and sun and the rotation of the earth [44]. The use of tidal energy theoretically affects the energy of the earth's rotation, but in fact this effect is basically negligible. Therefore, tidal energy is resourcerich renewable energy [45]. It also uses the potential energy difference of water. The current technology is divided into tidal stream generator, tidal barrage, dynamic tidal power, tidal lagoon. Power generation is generated by natural energy from the tide or by adding artificial induction.

\subsubsection{Problems of hydropower}

The problems facing hydropower development lie in the following aspects. The first is the consumption of hydropower caused by the imbalance of supply and demand and the severe hydropower consumption situation. For example, in China, the southwest region is rich in hydropower resources and has good development conditions, but the economic development of these areas is at a relatively low level (Table 1), the infrastructure is not sound, and the economic structure is single. Simultaneously, because the rivers such as the Lancang River and the Yarlung Zangbo River are international rivers, possible international disputes will affect hydropower development. Therefore, the hydroelectric power generation capacity in Southwest China cannot be used effectively, resulting in a large amount of waste energy [46].

As the construction of hydropower stations will occupy a large amount of land area and destroy vegetation, it will lead to loss of cultivated land and soil erosion. The dam has changed part of the wildlife habitat in rivers and reservoirs, threatening the lives of these creatures. During the construction of hydropower stations, noise and dust have an impact on the environment, and earthwork activities affect the geological environment. The rise of the groundwater level around the reservoir will cause the land to be submerged, thereby changing the regional ecological environment.
Overall, hydropower migration is an important part of the construction of water conservancy and hydropower projects, and it is also a complex link involving social development. The migration process and subsequent related policies are also issuing that need to be faced.

Table 1. Distribution of water resources in China [46]

\begin{tabular}{|l|l|l|l|l|}
\hline Area & $\begin{array}{l}\text { Theoretic } \\
\text { al power } \\
\text { generation } \\
\text { /TW }\end{array}$ & $\begin{array}{l}\text { Technologi } \\
\text { cal } \\
\text { developmen } \\
\text { t/TW }\end{array}$ & $\begin{array}{l}\text { Theoreti } \\
\text { cal } \\
\text { proportio } \\
\text { n/\% }\end{array}$ & $\begin{array}{l}\text { Technol } \\
\text { ogy } \\
\text { proportio } \\
\text { n/\% }\end{array}$ \\
\hline North & 1202.01 & 231.12 & 2.00 & 1.60 \\
\hline $\begin{array}{l}\text { Northe } \\
\text { ast }\end{array}$ & 1143.42 & 416.63 & 1.90 & 2.80 \\
\hline $\begin{array}{l}\text { East } \\
1\end{array}$ & 2432.35 & 718.76 & 4.00 & 4.20 \\
\hline $\begin{array}{l}\text { Centra } \\
1\end{array}$ & 3081.95 & 1969.45 & 5.10 & 9.30 \\
\hline South & 2150.75 & 1028.01 & 3.50 & 4.60 \\
\hline $\begin{array}{l}\text { South } \\
\text { west }\end{array}$ & 42951.12 & 18023.86 & 70.60 & 66.70 \\
\hline $\begin{array}{l}\text { North } \\
\text { west }\end{array}$ & 7867.51 & 2351.47 & 12.90 & 10.80 \\
\hline
\end{tabular}

\section{Carbon capture and sequestration (CCS)}

CCS is divided into two parts; one part is carbon capture, and the other part is carbon sequestration.

\subsection{Carbon capture}

There are three different configurations of carbon capture technology: post-combustion, pre-combustion and oxyfuel combustion.

1) Oxy-fuel combustion is to filter the nitrogen in the air, leaving a higher concentration of oxygen stream to participate in the combustion, thereby obtaining a high concentration of carbon dioxide and water vapor. The process of separating water vapor by cooling to capture carbon dioxide [47].

2) Pre-combustion is to partially oxidize fossil fuels to produce carbon monoxide and hydrogen, and then the product will pass through a water-gas shift reactor to form carbon dioxide and hydrogen, and finally separate the two. Hydrogen is a clean fuel, and the remaining carbon dioxide is captured [48].

3) Post-combustion refers to the process of collecting the burned materials and separating carbon compounds after the fuel is burned. Compared with the first two technologies, post-combustion is more feasible because it can add collection and separation devices to existing power stations. The limitation is that the added device will 
generate energy loss, and the separation device needs to process a mixture containing multiple substances, including metal compounds, and these substances may have a negative impact on the entire process [49].

\subsection{Carbon sequestration}

Carbon sequestration includes biological processes, physical processes and chemical processes.

The method of biological carbon sequestration mainly includes the absorption of carbon by photosynthesis of plants and microorganisms. Development directions include forestry, organic agriculture, wetland maintenance, etc. When the trees die, they can be used in the construction industry to achieve long-term storage [50]. In terms of agriculture, the promotion of organic agriculture is conducive to the use of crops and their relationship with the carbon cycle, to permanently store carbon in the soil, while restoring arable land is also conducive to this way of carbon sequestration [51].

The physical carbon sequestration process refers to the long-term storage of the collected carbon dioxide through physical means. This method is mainly geological storage.

Geological storage refers to the storage of the captured carbon dioxide underground, generally depleted oil and gas reservoirs, saline formations, or deep, un-minable coal beds [52]. The depleted oil and gas reservoir is similar to a warehouse. Coal seam can effectively absorb carbon dioxide and prevent it from escaping to the surface. The underground brine aquifer is an effective storage area for chemical waste. Carbon dioxide can be dissolved in the brine aquifer to generate carbonate [53, 54]. When injected, the carbon dioxide will be compressed to approximately 100 bar and become a supercritical fluid. The global storage capacity of oil and natural gas reservoirs is estimated to be $675-900 \mathrm{Gt}$ of carbon dioxide, and the un-minable coal seams are estimated to be $15-200 G t$. The deep salt layer has the largest capacity, estimated to be 1000-10000Gt [55] . Physical and biological methods can also be combined to collect biomass energy and store the carbon dioxide produced. This industry is also known as Bio-energy with carbon capture and storage (BECCS).

Generally speaking, these areas are more suitable for geological storage [55]:

1) Basins formed in the middle of the continent;

2) Basins formed near the edge of a stable continental plate;

3) Basins behind the mountains formed by the collision of plates;

4) Fold belts;

5) Other elevated areas.

The chemical carbon sequestration process is to make carbon dioxide and minerals react to form stable compounds for stable storage. It has been discussed above that carbon dioxide produces stable carbonate in the salt water layer, and the carbon dioxide is dissolved in water and injected into the underground basalt to form carbonate minerals [54]. Electrochemistry can also be used to convert water-soluble carbon dioxide into solids [57].

\subsection{Present situation and problems of CCS}

As of September 2017, the Global CCS Institute has identified 37 large-scale CCS facilities in its 2017 CCS Global Status Report. Among them, 21 projects are running or under construction, capturing more than $30 \mathrm{Mt}$ carbon dioxide each year [58]. Commercial projects focus on energy and heavy industry, as well as specialized projects for carbon storage and further research on carbon capture.

CCS currently faces many challenges. In terms of CCS policies, some countries have formulated a series of CCS incentive measures from the perspective of carbon pricing, tax relief, and emission standards. In 2018, the United States passed an amendment to the Carbon Storage Tax Act (45Q), which increased the tax-free subsidy for $\mathrm{CO} 2$ storage in saltwater aquifers to $\$ 50 / \mathrm{t}$ and the tax-free subsidy for $\mathrm{CO} 2$ utilization to $\$ 35 / \mathrm{t}$ [59]. However, although China has invested a certain amount of funds in supporting the development and demonstration of CCS projects, the fiscal and taxation, and market-based incentive mechanisms directly applicable to CCS technology are still unclear. In addition, the cost of CCS is still high. Most of the carbon dioxide treatment costs for most demonstration projects in China are between \$55$85 / t$ [60]. Immature technology cannot quickly reduce costs through large-scale commercial use, which leads to little interest from investors. Moreover, CCS ecological security risk prevention is facing tremendous pressure. In theory, it is feasible to store carbon dioxide underground, but the geological conditions are complicated, and there is currently no clear CCS guidance plan, and there are hidden dangers.

\section{Discussion}

\subsection{Existing measures of carbon neutrality}

The realization of carbon neutrality requires industrial transformation, such as new energy vehicles and reducing the carbon footprint. Denmark is conducting an energy system analysis of $100 \%$ renewable energy. After more than 40 seminars, 1,600 participants discussed and designed a model of the Danish future energy system (Fig. 8). 


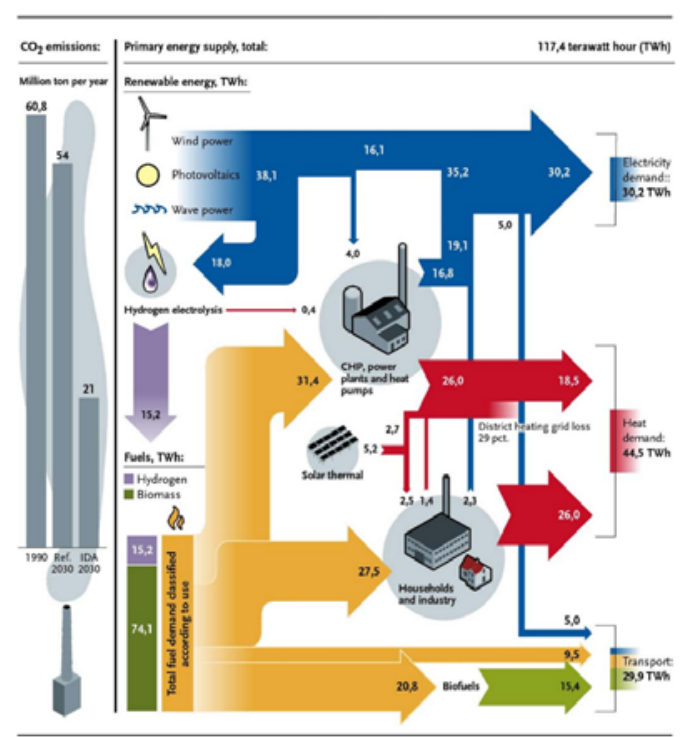

Fig. 8. Flow diagram of the $100 \%$ renewable energy system [61]

To achieve this goal, Denmark has to reform many aspects of society, such as using ships and trains to replace part of road transportation, using micro fuel cells to replace natural gas boilers, promoting central heating, and increasing investment in renewable energy. This has a strong impact on society, and the country needs to propose mutually-win solutions to the people.

For regions that require large amounts of energy imports, achieving the goal of carbon neutrality is conducive to the development of the local energy industry. Hans Christian Gils and others analyzed the Canary Islands. This is an archipelago that relies on energy imports. They proposed and analyzed a way to supply $100 \%$ renewable energy in the Canary Islands. The results show that it is feasible to use local resources to provide carbonneutral energy (Fig. 10).

Nasim Pour and others studied the application of Australia's BECCS industry in the power sector. They found that Australia's BECCS has the potential to provide 25 MT of negative carbon dioxide emissions per year and 13.7 TWh of electricity, and can enhance the flexibility of Australia's energy flexibility and diversity [64].

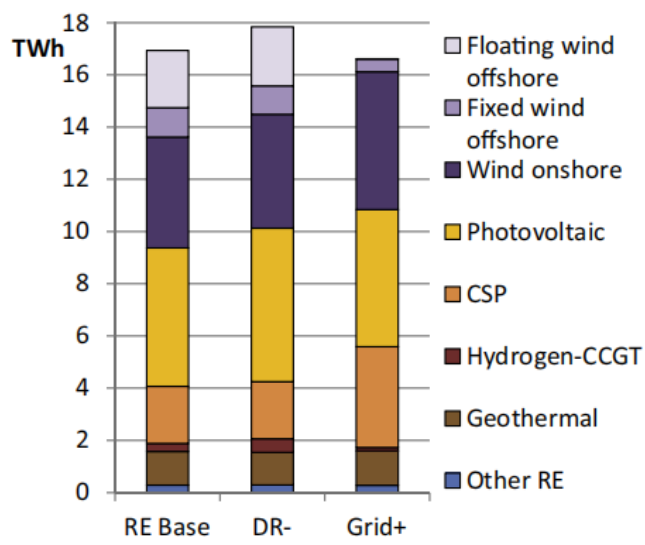

Fig. 9. Total power generation in the three sub-scenarios. Other RE comprises biomass, hydro, wave power, and fuel cells [62]

\subsection{Challenges of carbon neutrality}

The realization of carbon neutrality still faces many challenges. According to the UN Energy Agency's "Emission Gap Report 2020", If governments invest in climate protection actions in the recovery process after the outbreak, they will work to increase the contribution targets set by their countries before the United Nations Climate Change Conference (COP 26) to be held in Glasgow in November 2021 and commit to achieving "Net zero emissions". This is expected to reduce global carbon emissions to the point where the temperature reaches "The $2{ }^{\circ} \mathrm{C}$ Global Temperature Target". However, the report also pointed out that the world's richest $1 \%$ of the population emits more than twice the emissions of the poorest $50 \%$. The wealthy need to reduce their carbon footprint by at least 30 times to be consistent with the goals of the Paris Agreement, which is more difficult to achieve. Therefore, achieving carbon neutrality not only requires the support of science and technology, but people's low-carbon awareness will also have an important impact [64].

Economic pressure is also a challenge. The high cost of solar energy and the low-cost performance of CCS technology discussed above have a negative impact on the development of carbon neutrality. At the same time, the development of carbon neutral technology will also generate economic pressure. For example, the development of renewable energy vehicles requires the government to invest in supporting facilities, and the application of carbon capture in power plants also requires investment in carbon separation technology and equipment. These will reduce the society's interest in carbon neutral development [61].

In addition, the geographical environment will also have an impact on the development of carbon neutrality. For areas with a small geographic location and a large population, it is difficult to develop large-scale wind power and solar power, and it is difficult to develop hydropower in inland and plain areas. In addition, the development of carbon sequestration will also be restricted. Florian Kraxner and others studied the potential of the BECCS project in South Korea [56]. They concluded that a large number of areas in South Korea are covered by forests and have a high potential for biomass energy development. However, due to topography, their carbon sequestration potential is limited.

\section{Conclusion}

Carbon neutrality is an important goal for future development, and its essence is a net carbon emission society. In order to achieve this goal, the development of renewable energy to completely replace fossil fuels and the use of CCS technology to achieve negative carbon emissions to offset necessary carbon emissions are two important ways. This article discusses the development prospects and development challenges of these aspects based on some cases. The significance of this research is to systematically summarize the current development of the above-mentioned industries, explain their application 
prospects through case studies, and point out future development goals by citing development deficiencies and problems conducive to future research in these areas.

\section{Reference}

1. What is carbon neutrality and how can it be achieved by 2050? | News | European Parliament. https://www.europarl.europa.eu/portal/en. 2019-0310 (2020)

2. Carbon-Neutral Is Hip, but Is It Green?. The New York Times, published 2007-04-29, accessed 2007-08-03.

3. Sutter, John D.; Berlinger, Joshua. Final draft of climate deal formally accepted in Paris. CNN. Cable News Network, Turner Broadcasting System, Inc. (2015-12-12)

4. Adoption of the Paris agreement-by the PresidentDraft decision -/CP.21. UNFCCC. 2015-12-12. Archived from the original on 2015-12-12 (2015)

5. Paris Agreement, FCCC/CP/2015/L.9/Rev.1. UNFCCC secretariat. Archived from the original on 12 December 2015 (2015)

6. Kaufman, Mark. The devious fossil fuel propaganda we all use. Mashable, (2020)

7. Bui, Mai; Adjiman, Claire S.; Bardow, André; et al. Carbon capture and storage (CCS): the way forward. Energy \& Environmental Science. 11(5): 1062-1176. doi:10.1039/C7EE02342A.

8. Statistical Review of World Energy. https://www.bp.com/content/dam/bp/businesssites/en/global/corporate/pdfs/energyeconomics/statistical-review/bp-stats-review-2020full-report.

9. J.F. Manwell , J.G. McGowan, and A.L. Rogers . Wind Energy Explained: Theory, Design and Application (2nd ed), John Wiley \& Sons : Chichester ( 2009 ).

10. Tony Burton et al., (ed), Wind Energy Handbook, John Wiley \& Sons, ISBN 0471489972, page 65.

11. Wind energy Frequently Asked Questions. British Wind Energy Association. Archived from the original on 19 April 2006 (2006)

12. What are the pros and cons of onshore wind energy? Grantham Research Institute on climate change and the environment (2020)

13. Royal Society for the Protection of Birds (RSPB). www.rspb.org.uk.

14. www.batsandwind.org.

15. J.C. Wilson. Offshore wind farms: their impacts, and potential habitat gains as artificial reefs, in particular for fish, University of Hull, www.hull.ac.uk/iecs/pdfs/wilsonmsc2007 (2007).

16. Rühle, Sven (2016-02-08). Tabulated Values of the Shockley-Queisser Limit for Single Junction Solar Cells. Solar Energy. 130: 139-147. Bibcode: 2016SoEn..130..139R. doi:10.1016/j.solener (2016)

17. Goetzberger A. Solar cells: past, present, future. Sol
Energy Mater Sol Cells. 2002;74(1-4):1 - 11. https://10.1016/10.1016/S0927-0248(02)00042-9.

18. Goetzberger A, Hebling C, Schock H - W. Photovoltaic materials, history, status and outlook. Mater Sci Eng $R$ Reports, 40(1):1 - 46. https://10.1016/10.1016/S0927-796X(02)00092 - X (2003)

19. https://onlinelibrary.wiley.com/.

20. Guerrero-Lemus R, Martínez-Duart J. Concentrated solar power. Renew Energies CO2 (2013)

21. Gee JM, Schubert WK, Basore PA. Emitter wrap through solar cell, 265-270 (1993)

22. Shah A, Torres P, Tscharner R, Wyrsch N, Keppner H. Photovoltaic technology: the case for thin-film solar cells. Science, 285(5428):692-698. https://10.1126/science.285.5428.692 (1999)

23. Cadmium telluride department of energy. https://www.energy.gov/eere/sunshot/cadmiumtelluride. (2017)

24. Spanggaard H, Krebs FC. A brief history of the development of organic and polymeric photovoltaics. Sol Energ Mat Sol C, 83(2-3):125-146 (2004)

25. American Chemical Society. Chemical and engineering news: "news edition" of the American Chemical Society. The American Chemical Society (1942)

26. McMeekin DP, Sadoughi G, Rehman W, et al. A mixed-cationlead mixed-halide perovskite absorber for tandem solar cells. Science(80-). 351(6269): 151 155. https://10.1016/10.1126/science.aad5845 (2016)

27. Grätzel M. Dye-sensitized solar cells. J Photochem Photobiol C; 4(2):145-153. https://10.1016/10.1016/S1389-5567(03)00026-1 (2003)

28. Deutsches Zentrum für Luft- und Raumfahrt (DLR). BINE Informationsdienst: Themeninfo: Solarthermische Kraftwerke-Parabolic trough collector technology.

29. NREL.gov Concentrating Solar Power Projects in the United States, 17 February 2014.

30. Müller-Steinhagen H, Trieb F. Concentrating solar power: areview of the technology. Ingenia, (18):4350. https://10.1016/10.1126/science.1168539 (2004)

31. Renewable Energy Agency I. Renewable energy cost analysis: concentrating solar power (2012)

32. Three solar modules of world's first commercial beam-down tower Concentrated Solar Power project to be connected to grid (2019)

33. Heath GA, Burkhardt Iii JJ. Meta - analysis of estimates of life cycle greenhouse gas emissions from concentrating solar power preprint meta-analysis of estimates of life cycle greenhouse gas emissions from concentrating solar power. PIX. 2011;16560. 
34. Prakash R, Bhat IK. Energy, economics and environmental impacts of renewable energy systems. Renew Sustain Energy Rev, 13(9):2716-2721 (2009)

35. Timilsina GR, Kurdgelashvili L, Narbel PA. Solar energy: markets, economics and policies. Renew Sustain Energy Rev, 16(1):449 - 465. https://10.1016/10.1016/j.rser.2011.08.009 (2012)

36. https://www.electricityforum.com/hydroelectricity.

37. Cleveland, Cutler J.; Morris, Christopher G. Handbook of Energy: Chronologies, Top Ten Lists, and Word Clouds. Elsevier Science. p. 44. ISBN 9780-12-417019-3 (2013)

38. Hydroelectric facility. https://energyeducation.ca/encyclopedia/Hydroelectr ic_facility.

39. Variable Speed Is Key To World's Biggest Pumped Hydro Energy Storage Project, China's Fengning Plant (2020)

40. TVA-Raccoon Mountain. www.tva.gov. Tennessee Valley Authority. Retrieved 3 April 2018.

41. Raghunath, H.M. Hydrology: principles, analysis, and design(Rev. 2nd ed.). New Delhi: New Age International. p. 288. ISBN 81-224-1825-2 (2009)

42. Douglas T, Broomhall P, Orr C. Run-of-the-River Hydropower in BC: A Citizen's Guide to Understanding Approvals, Impacts and Sustainability of Independent Power Projects Archived 2008-08-28 at the Wayback Machine. Watershed Watch (2007)

43. https://en.wikipedia.org/wiki/Iitti.

44. DiCerto, JJ. The Electric Wishing Well: The Solution to the Energy Crisis. New York: Macmillan (1976)

45. Turcotte, D. L.; Schubert, G. Geodynamics (2nd ed.). Cambridge, England, UK: Cambridge University Press. pp. 136-137. ISBN 978-0-521-66624-4 (2002)

46. Rui Li, Zhizhou Du, Jiagang Yang. Current Status and Prospects of China's Hydropower Development. Water Science and Engineering Technology, 38(06), Page 73-78 (2019)

47. Bui, Mai; Adjiman, Claire S.; Bardow, André. et al. Carbon capture and storage (CCS): the way forward. Energy \& Environmental Science, 11(5): 1062-1176. doi:10.1039/C7EE02342A. ISSN 1754-5692.

48. Bryngelsson, Mårten; Westermark, Mats. Feasibility study of $\mathrm{CO}_{2}$ removal from pressurized flue gas in a fully fired combined cycle: the Sargas project. Proceedings of the 18th International Conference on Efficiency, Cost, Optimization, Simulation and Environmental Impact of Energy Systems. pp. 70310 (2005)

49. Sumida, Kenji; Rogow, David L.; Mason, Jarad A. et al. Carbon Dioxide Capture in Metal-Organic Frameworks. Chemical Reviews, 112(2): 724-781. doi:10.1021/cr2003272. PMID 22204561.

50. Chazdon, Robin; Brancalion, Pedro. Restoring forests as a means to many ends. Science. 365(6448): 24-25. Bibcode: Sci.365.24C. doi:10.1126/science.aax9539. PMID 31273109. S2CID 195804244 (2019)
51. Blakemore, R.J. Non-flat Earth Recalibrated for Terrain and Topsoil. Soil Systems. 2(4): 64. doi:10.3390/soilsystems2040064.

52. Aydin, Gokhan; Karakurt, Izzet; Aydiner, Kerim. Evaluation of geologic storage options of $\mathrm{CO} 2$ : Applicability, cost, storage capacity and safety. Energy Policy. Special Section on Carbon Emissions and Carbon Management in Cities with Regular Papers. 38(9): 5072-5080. doi:10.1016/j.enpol (2010)

53. Kheshgi, H.S.. Sequestering atmospheric carbon dioxide by increasing ocean alkalinity. Energy. 20(9): 915-922. doi:10.1016/0360-5442(95)00035-F.

54. Werner, C; Schmidt, H-P; Gerten, D; Lucht, W; Kammann, C. "Biogeochemical potential of biomass pyrolysis systems for limiting global warming to $1.5{ }^{\circ} \mathrm{C} "$. Environmental Research Letters, 13(4): 044036. doi:10.1088/1748-9326/aabb0e (2018)

55. Smit, Berend; Reimer, Jeffrey A.; Oldenburg, Curtis M.; Bourg, Ian C. Introduction to Carbon Capture and Sequestration. London: Imperial College Press. ISBN 978-1783263288 (2014)

56. Florian Kraxner; Kentaro Aoki; Sylvain Leduc et al. BECCS in South Korea-Analyzing the negative emissions potential of bioenergy as a mitigation tool. Renewable energy, 61, p.102-108 (2014)

57. Frank Zeman. Energy and Material Balance of $\mathrm{CO} 2$ Capture from Ambient Air. Environ. Sci. Technol, 41(21): 7558-63. Bibcode:2007EnST.41.7558Z. doi:10.1021/es070874m. PMID 18044541.

58. Global CCS Institute Media Releases. Retrieved 2019-3-18.

59. [USC04] 26 USC 45Q: Credit for carbon oxide sequestration. uscode.house.gov. Retrieved 2018-1208 .

60. Shiyan Chang, Dingqian Zheng, Meng Fu. Biomass combined with carbon capture and storage technology (BECCS) under $2^{\circ} \mathrm{C} / 1.5^{\circ} \mathrm{C}$ temperature control target. Global Energy Internet, 03 (2019)

61. Lund H; Mathiesen, B.V. Energy system analysis of $100 \%$ renewable energy systems - The case of Denmark in years 2030 and 2050. Energy (Oxford), 34(5), p.524-53 (2009)

62. Hans Christian Gils; Sonja Simon. Carbon neutral archipelago-100\% renewable energy supply for the Canary Islands. Applied energy, 188, p.342-355 (2017)

63. Nasim Pour; Paul A. Webley; Peter J. Cook. Opportunities for application of BECCS in the Australian power sector. Applied energy, 224, p.615635 (2018)

64. Emissions Gap Report 2020. https://www.unep.org/emissions-gap-report-2020. 